\title{
THE MEANING OF CANADIAN CITIZENSHIP IN LIGHT OF DUAL CITIZENSHIP AND MULTICULTURALISM IN CANADA
}

By

Viktoria Mirtchevsky, BA, Ryerson University, 2014

\author{
A Major Research Paper \\ Presented to Ryerson University \\ In partial fulfillment of the requirements for the degree of \\ Master of Arts \\ In the program of \\ Immigration and Settlement Studies
}

Toronto, Ontario, Canada, 2014

(C) Viktoria Mirtchevsky 


\section{AUTHOR'S DECLARATION FOR ELECTRONIC SUBMISSION OF A MAJOR RESEARCH PAPER (MRP)}

I hereby declare that I am the sole author of this Major Research Paper. This is a true copy of the MRP, including any required final revisions, as accepted by my examiners.

I authorize Ryerson University to let this MRP to other institutions or individuals for the purpose of scholarly research.

I further authorize Ryerson University to reproduce this MRP by photocopying or by other means, in total or in part, at the request of other institutions on individuals for the purpose of scholarly research.

I understand that my MRP may be made electronically available to the public.

Viktoria Mirtchevsky 


\title{
THE MEANING OF CANADIAN CITIZENSHIP IN LIGHT OF DUAL CITIZENSHIP AND MULTICULTURALISM IN CANAD
}

\author{
Viktoria Mirtchevsky \\ Master of Arts 2014 \\ Immigration and Settlement Studies \\ Ryerson University
}

\begin{abstract}
With multiculturalism informing policy formation related to immigration and settlement in Canada, dual citizenship is accepted. Many have argued that dual citizenship is problematic when it creates dual, and often times, competing loyalties, interests, and priorities; while others argue that dual citizenship is actually a positive development that is consistent with the Canadian culture of acceptance, tolerance and multiculturalism. This MRP will examine the connection between multiculturalism, the legality of dual and multiple citizenship in Canada and their effect on the meaning of Canadian citizenship for naturalized Canadian citizens holding dual or multiple citizenships.
\end{abstract}

Key Words: Citizenship, Dual Citizenship, Multiculturalism, Jus Domicili, Transnationalism, Postnationalism, Traditional Citizenship, Canadian Citizenship 


\section{Table of Contents}

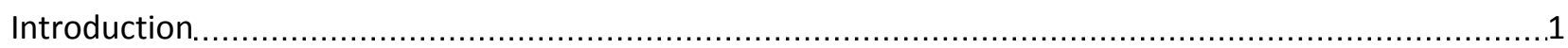

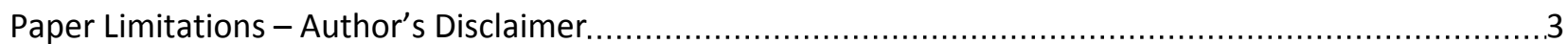



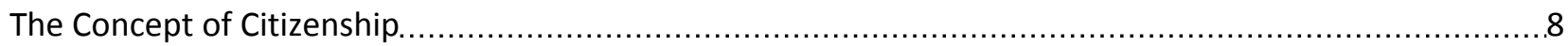

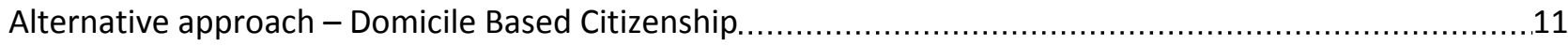

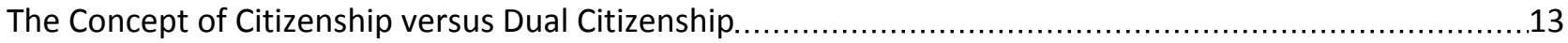



Current Debate on Dual and Multiple Citizenship in Canada.....................................................

Traditional, Transnational and Postnational Positions on Dual Citizenship............................................ 22

Multiculturalism

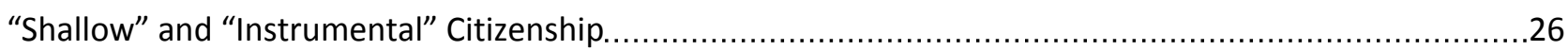

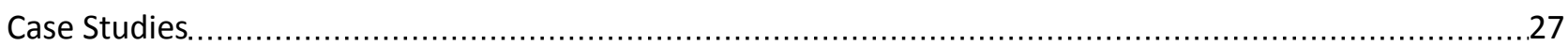

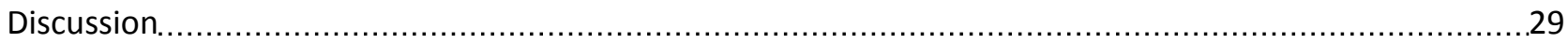

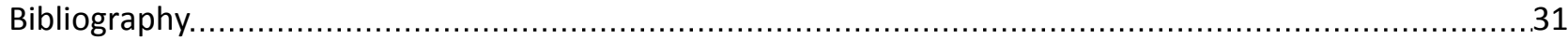




\section{Introduction}

With multiculturalism informing policy formation related to immigration and settlement in Canada, dual citizenship is accepted. Many have argued that dual citizenship is problematic when it creates dual, and often times, competing loyalties, interests, and priorities; while others argue that dual citizenship is actually a positive development that is consistent with the Canadian culture of acceptance, tolerance and multiculturalism. In light of this debate, many have begun to wonder about the effects of the legality of dual citizenship the meaning of Canadian citizenship: its meaning, its role in national identity formation, and the attitudes held by immigrants holding dual citizenship in Canada (Ronkainen, 2001;Macklin \& Crepeau, 2010; Erman \& Follesdal, 2012;Serejsen, 2008; Bloemraad, 2004; Conway, Potter \& Bernard, 2008; Hurst, 2005; Waters, 2003; Manuh, 1998; Wong, 2007; Murphy, 2006; Satzewich, 2007; Banting \& Kymlicka, 2010).Recent years have witnessed many heated discussions on the stages of the Canadian media and academia re-evaluating the validity of the Canadian immigration and settlement policies (Baubock, 2002; Baubock, 2009; Kymlicka, 2011; Levanon \& Lewin-Epstein, 2010; Stoker, Mason \& McGrew, 2011; Bloemraad, Korteweg \& Yurdakul, 2008; Cohen, 2007; Banting, 2010; Ronkainen, 2001; Macklin \& Crepeau, 2010; Erman \& Follesdal, 2012; Serejsen, 2008; Bloemraad,2004; Conway, Potter \& Bernard, 2008; Hurst, 2005; Waters, 2003; Manuh, 1998; Wong, 2007; Murphy, 2006; Satzewich, 2007; Banting \& Kymlicka, 2010). With challenges to multiculturalism stemming from the European experience, many Canadians have begun to question the validity of the multiculturalism policy and the immigration and settlement policies that were development under its influence. An examination through available academic literature of the possible effects of dual citizenship on Canadian citizenship and the immigrants in Canada 
who hold dual citizenship would be a valuable addition to the current debate on the topic.

This paper will attempt to demonstrate that, informed and encouraged by multiculturalism and transnational practices, the legality of dual citizenship in Canada contributes to the devaluation of Canadian citizenship, resulting in "shallow" or "instrumental" Canadian citizenship held by immigrants with dual citizenship. I will begin by tracing the origins of modern citizenship as we know it in order to set the stage for a discussion on the concept of citizenship. I will examine alternative approaches to the concept of citizenship and attempt to evaluate those against the original precepts of the concept. Thereafter, I will engage in a discussion on the history of citizenship in Canada including the process by which dual citizenship has been legalized. I will then proceed to summarize the current debate on dual citizenship including the competing positions held by proponents of traditional, transnational and postnational schools of thought. I will tie the concept of multiculturalism and review how it relates to dual citizenship. Then, I will turn my attention to the concepts of "shallow" and "instrumental" citizenship and identify how these concepts have been developed and defined in the current literature on the topic. Last but not least, I will present several case studies that have been conducted on the subject of dual citizenship in relation to national identity formation to articulate some of the key finding that support or refute the principles of "shallow" and "instrumental" citizenship. 


\section{Paper Limitations - Author's Disclaimer}

Before proceeding, however, a limitation statement is appropriate. This paper will focus on Canadian naturalized citizens holding dual or multiple citizenships only. The arguments in this paper do not extend to all immigrants in Canada, naturalized or otherwise. This paper will argue that due to the legality of multiple citizenships in Canada and the attitude and environment created by multiculturalism, dual citizens are not encouraged to form meaningful attachments to Canada. This is a criticism of the relevant Canadian policies, and not of the dual citizens themselves. I will refer to "shallow" and "instrumental" citizenship throughout the paper when referring to specific effects of the legality of dual and multiple citizenships in Canada as well as the policy and concept of multiculturalism; by these terms I mean very specific notions, as defined in the "shallow" and "instrumental" Citizenship section of this paper. I do not use these terms to criticize the group of citizens discussed in this paper. Rather, these terms are used to describe the results of the policies set by the government of Canada that affect Canadian citizenship. Furthermore, this paper is dedicated to a very narrow topic - that of the specific effects of dual and multiple citizenships and multiculturalism on Canadian citizenship held by a specific group of naturalized citizens in Canada. Therefore, this paper will not delve into wider issues within the Canadian immigration and settlement system.

To that effect, wider criticisms of the Canadian immigration and settlement system, including criticisms of its selection mechanism of landed immigrants and its programs design to limit acceptance of immigrants into permanent settlement by way of temporary foreign workers programs will not be included. It is understood that Canada is being instrumental in its selection of immigrants to which it extends the right of path to naturalization. This instrumentality, with its 
merits and challengers, however, is not relevant to the discussion to ensue and therefore will not be included.

Additionally, I recognize that the evidence for the formation of "shallow" and "instrumental" citizenship is allusive in this specific instance. How does one go about measuring the loyalty, emotional and moral attachment, and valuation of Canadian citizenship as held, felt and understood by naturalized Canadian citizens with multiple citizenships? While there might be numerous studies devoted to the measurement, or at least a deeper understanding of the value of Canadian citizenship as held by naturalized citizens, I do not believe that these would contribute to the discussion. Since this paper examines a very specific group of individuals - those who have naturalized into Canada while holding at least one additional citizenship elsewhere, I have chosen to include three specific case studies dealing with specific instances of this occurrence. Thus, the section "Case Studies" is meant to demonstrate how the arguments presented in this MRP plays out in the "real" world. This evidence is to demonstrate a very narrow effect - as defined by the terms "shallow" and "instrumental" citizenship in this paper. It does not extend to all Canadian naturalized citizens holding multiple citizenships, but is rather a sample of three groups that support the arguments. I fully acknowledge that further research is necessary. I also would like to be very clear that this is a very narrowly focused MRP and is not intended to made conclusions beyond its focus.

Engaging the available literature on the feelings of belonging and attachment of naturalized Canadian citizens to Canada is beyond the scope of this paper. This engagement will only serve to expand the topic to a wider group and will force the consideration of a wider array of effects than intended by this paper. As this paper does not speak to general feelings of 
belonging and attachment, but rather focuses on the narrow definitions of "shallow" and "instrumental" citizenship, this type of wider discussion wouldnly serve to confuse the matter. I do acknowledge, however, that a wider discussion and further research is necessary in this field, but am limited to the issue at hand in this MRP.

Last but not least, since this paper problematizes the legality of dual and multiple citizenships in Canada, it effectively argues for single citizenship in Canada. The reason for this argument is presented in this paper through the criticism of the effects of multiple citizenships on the value of Canadian citizenship, but it has to be recognized that there are challenges to single citizenship that would need to be overcome should Canada go that route. Single citizenship, nationalism, and patriotism have negative connotations as related to segregation, separatism, and discrimination. It delineates very clearly and definitively who belongs and who does not belong and reinforces an "us versus them" attitude. However, in our globalized world with open access to information and transportation it does not have to mean that. Diversity is not directly related to citizenship. Single citizenship would not mean an end to immigration, and immigration to Canada should not be limited to a single source nation or area, as it was in the early days of Canadian citizenship. Migration from all over the world to Canada leads to diversity in Canada, and should not be stopped. Again, this is not the argument of the paper. This paper merely argues for single citizenship in order to ensure that Canadian citizenship is held in high esteem and that Canadian citizens are attached to only one nation state. It does not argue for any other changes in the immigration and settlement system in Canada. 


\section{Modern Citizenship - Invented}

Citizenship as we know it was invented in the French Revolution through the inventions of the nation-state and the modern institutions and ideology of national citizenship (Brubaker, 1992). Before the French revolution, during the Ancient Regime, "citizenship was not consistently defined or systematically codified; it was determined in an ad hoc manner in particular cases to make it accord with legal judgements about inheritance rights" (Brubaker, 1992, p.39). In order to understand how the French revolution changed the meaning of citizenship to mean belonging to a specific territory and society and ascribe it great value and power to determine rights and obligations within the nation, one has to look at it as four revolutions in one: a bourgeoisie revolution, a democratic revolution, a national revolution, and a bureaucratic, state strengthening revolution (Brubaker, 1992).

The bourgeois revolution established the bourgeois society, which created the social and legal framework for the establishment of equality before the law and of the legal right to private property (Brubaker, 1992). This revolution established common rights, common obligations and formalized the concept of equality before the law (Brubaker, 1992). Thus, unmediated, undifferentiated, individual membership of the state was created for all those who belong to the state (Brubaker, 1992).

The democratic revolution focused on political rights which derived from the person's equality before the law, which is a distinct component of modern citizenship (Brubaker, 1992); and the national revolution created a "nation une et indivisible, composed of legal equal individuals standing in a direct relationship to the state, out of a patchwork of overlapping corporate jurisdictions and pervasive corporate privilege; and the substitution of a militant, mobilized 
nationalism for the cosmopolitanism, the prevailing indifference to nationality and citizenship of the old regime" (Brubaker, 1992, p.43). Thus, both the nation state and nationalism were established, and with those, the concept of foreigner was engendered, not only as a legal category "but as a political epithet, invested with a psychological charge it formerly lacked, and condensing around itself pure outsiderhood" (Brubaker, 1992, p.47). Most importantly, the French Revolution as a whole created a legal and moral frontier between members of different nation-states. 


\section{The Concept of Citizenship}

The concept of citizenship is very complex and has been theorized to mean many things in different contexts. Citizenship could mean the belonging of an individual to a territorial state, it could mean belonging to a community by virtue of living in that community; it could also mean social entitlements within a community, as well as refer to responsibilities placed on an individuals. At its broadest sense, national citizenship can be understood as "a bundle of rights, responsibilities, obligations, entitlements, and loyalties which constitute membership of a territorially bounded political community" (Stoker, Mason \& McGrew, 2011). Within this understanding of citizenship one needs to distinguish between the civic boundaries that define the political, legal and social status of an individual, and the territorial boundaries which define the political authority and legal jurisdiction of a nation (Loegaard, 2012). As Loegaard explains:

civic boundaries separate citizens from denizens and transients within the same territory by assigning different rights and duties to the individuals of each category, where the rights of citizens include but go beyond those of denizens or transients. Territorial boundaries separate different states by specifying the scope of the authority and jurisdiction of each sovereign power, the rights of each state may be the same but are specified so as to not overlap and conflict conflicts of jurisdiction

(Loegaard, 2012)

Furthermore, it is possible to identify three dimensions of citizenship. Citizenship as status defines formal state membership and the rules to its access; citizenship as rights defines the formal capacities and immunities that are connected with the status of citizenship; and citizenship as identity which speaks to the shared beliefs and identity that connects the individual to the state or political community (Loegaard, 2012). 
Because formal citizenship - in its legal aspect - is tied to a territorial entity (the state) in that it is that entity that one either a citizen of or not, the onslaught of globalization, which refers to the "process of growing worldwide interconnectedness such that events and decisions in one region of the world can come to have significant consequences for distant communities" (Stoker, Mason \&McGrew, 2011, p.134), some suggest, means the erosion of the relevance and importance of the concept of citizenship (Granatstein, 2007; Hurst, 2005; Murphy, 2006; Manuh, 1998; Waters, 2003; Conway, Potter \& Bernard, 2008; Ronkainen, 2011; Cohen, 2007). Among several forces that work together in the process of globalization to diminish the role and significance of citizenship, such as political and economic multi state integration, a key factor is increased global temporary and permanent migration. It has been suggested that increased global migration leads to the strengthening of other sources of identity and loyalties other than nationalism (Stoker, Mason \& McGrew, 2011). These alternate sources of identity could be found in transnational religious, cultural and ethnic identities (Stoker, Mason \& McGrew, 2011).

This argument would support the notion that a policy of multiculturalism, where citizens and candidates for citizenship are encouraged to tightly hold on to their traditions, cultures and beliefs, even if those are in direct contradiction to Canadian traditions and beliefs, would further erode the notion of Canadian citizenship. The legality of multiple citizenships would seem to further complicate this issue. Furthermore, increased migration, more often than not, has resulted in the attribution of rights based on residency rather than citizenship - additionally reducing the importance and meaning of formal citizenship (Soysal, 1994). The above argument is based on the assumption that citizenship is more than just a legal status. As originally created in the French revolution, citizenship carries with it the notion of nationalism - the moral, emotional, and collective value and belief system which differentiates the citizens from non-citizens. 
Citizenship is not only a document, but rather a fraternity where national loyalty and pride are as big a part as the legal sense of the status. Thus, multiculturalism and residency based rights seem to be incompatible with the classic understanding of citizenship as a whole, and not as a legal status alone.

Others, on the other hand, have argued that the processes of globalization do not automatically condemn the meaning of formal citizenship, and it is really within the control of the state itself to manage the effects of globalization to safeguard its citizenship (Stoker, Mason \& McGrew, 2011). For example, openness to and participation in global markets can provide greater opportunities for sustained national economic growth and prosperity; when it comes to national sovereignty and autonomy, even if a state chooses to be part of a multilateral agreement, national governments have demonstrated the ability to effectively pool sovereignty in order to extend, through collective action, national control over external forces (Stoker, Mason \& McGrew, 2011). In response to increased migration, to ensure that citizenship remains meaningful, many states have responded by rethinking and altering their immigration and naturalization policies - a process that is currently taking place across Europe and North America (Stoker, Mason \& McGrew, 2011). And finally, debates about the merits and failures of multiculturalism are being debated on integration arena, as many have come to believe that national identity and a sense of national loyalty could be better served by an alternative approach. 


\section{Alternative approach - Domicile Based Citizenship}

Citizenship is traditionally based on the principles of jus soli and jus sanguinis. Jus soli refers to citizenship that is granted based on the person's place of birth, while jus sanguinis confers citizenship based upon ancestry. With increased global migration, an alternative in the form of jus domicilii has become prominent on the scholarly research arena. Jus domicilii, or citizenship based on domicile, would confer citizenship on those who can demonstrate effective residence, "in other words, a person is a citizen of the polity in which she or he resides independent of ancestry or location of birth" (Bauder, 2014, p.92).

At first glance, this seems to be a fair and "supremely liberal" alternative to traditional citizenship (Bauder, 2014, p.95). This allows migrants to choose the place where they want to live, become contributing members of that society, and thus be granted full membership and equal rights in that society. This completely eliminates the unequitable naturalization process that leaves much to the discretion of those who administer the policies, and effectively "implies that citizenship is a right for everyone who is a de facto resident in a political territory, independent of status" (Bauder, 2014, p.97).

However, a closer look at the implications of the domicile principle as a viable alternative to traditional citizenship in our ever mobile world raises some concerns. Firstly, it does not address the way in which migrants arrive and simply bestows rights upon residents within a territory. However, illegal migration, smuggling, and human trafficking are part and parcel of the immigration arena, and bestowing rights upon individuals who have crossed international borders illegally would mean rewarding illegal activity and admitting citizens who demonstrate a lack of respect to the nation's laws from the very first act of entering its borders. Secondly, 
national sovereignty and its right to choose who it admits within its borders will be usurped by the principle of domicile. The nation state is not merely a mechanism that dispenses rights, but it is also entrusted with the function of administering all its policies, creating safety nets for its citizenry and protecting its citizenry from external threats (Krasner, 2001). If it no longer has the right to choose who can and cannot enter its borders and obtain its citizenship, its ability to maintain its policies in a functional manner and protect its citizenry will diminish.

Thirdly, the principle of domicile completely ignores the fact that citizenship is not merely a legal right. It has emotional and moral connotations that will continue to be eroded if the domicile principle is followed for granting citizenship. It will further contribute to the instrumentalization of Citizenship. Loyalty, nationalism and patriotism cannot mean much, if anyone can go anywhere and obtain citizenship by merely working and paying their taxes in that community. This principle will create a class of persons who move around depending on where the current state of affairs is more favorable to their objectives. Once the situation worsens in their current place of residence they will simply leave to a more prosperous place. Since no attachment or loyalty is required or even encouraged, there is no incentive in sticking by their nation of citizenship through rough times and caring about its affairs. 


\section{The Concept of Citizenship versus Dual Citizenship}

Originally, when dual citizenship appeared as a legal concept, it was viewed as a problematic state from an international relations, national policy, national security, voting, taxation, and diplomatic protection dimensions (Ronkainen, 2011). In addition, the fundamental objection to dual and multiple citizenships was that it went against the notion and understanding that proper citizenship required an "undivided loyalty from the citizens toward their state" (Ronkainen, 2011, p.247). With the effects of globalization taking shape, and with it, increased global migration, the views on dual and multiple citizenship have shifted (Ronkainen, 2011). Many migrant receiving nations have now adopted various policies to do with dual and/or multiple citizenship, and it is no longer considered to be the exception, but rather the rule (Conway, Potter $\&$ Bernard, 2008)..

While holding two or more citizenships may now be acceptable from a legal perspective, it still poses challenges when one considers the effects on the national identification of those citizens. National identification, as described by Ronkainen, has to do with feeling, knowing and doing (Ronkainen, 2011). Ronkainen writes:

National identification becomes apparent in feeling the similarity with fellow nationals, and feeling the loyalty, patriotism toward nation, state, and territory (home country and natural features); knowing about history, myths, language, and culture which also helps in doing and participating: accepting and negotiating about societal values, norms, and social order. Knowledge about language and culture give ways to understand oneself as part of the community, to understand national identity, to follow it, and to participate in discourse.

(Ronkainen, 2011) 
Thus, citizenship becomes an important definer and constructor of identity (Ronkainen, 2011). "Only identification to community brings along active patriotism", as citizenship represents cultural identity and belonging to a definedcommunity (Ronkainen, 2011). 


\section{The History of Citizenship and Dual Citizenship in Canada}

Canadian citizenship as a comprehensive legal status came into existence gradually. Until confederation there was no distinction between a Canadian citizen and a British citizen. With confederation, the federal government in Canada was granted jurisdiction over naturalization; however, Canadians remained British subjects. By exercising its power over naturalization, the Canadian parliament enacted statutory definitions of Canadian citizenship throughout the early $20^{\text {th }}$ century, but this legalization was intended only to specify who could and could not enter Canada, it did not displace British subjecthood. Leading up to the second world war, several membership classes existed including "aliens", "British subjects of Canada" (who had a right of entry into Canada only) and ordinary British subjects who had status throughout the British empire (Macklin \& Crepeau, 2010).

In 1931, the Statute of Westminster officially recognized Canada's independence, and in 1946, the Canadian parliament enacted the Canadian Citizenship Act. As a result, Canadian citizenship acquired autonomous legal existence, but Canadians remained also British subjects. The Canadian Citizenship Act restricted but did not prohibit dual citizenship - dual citizenship was allowed as long as citizenship in another country was not actively and voluntarily pursued. If one voluntarily acquired citizenship in another country, Canadian citizenship would automatically be lost. This restriction was removed with the enactment of the Citizenship Act of 1977 (Macklin \& Crepeau, 2010). It appears that there was very little debate in parliament about this change, and very little attention was given by the media to the removal of the restriction (Macklin \& Crepeau, 2010). Thus, Canada became one of the first nations to legalize dual and multiple citizenship. 
In terms of numbers, according to Statistics Canada, in 2001 approximately 557,000 people, or two percent of people living in Canada, held dual or multiple citizenship (Wong, 2007). While the numbers are not as easy to obtain, and Statistics Canada does not have an estimate on the number of Canadians who hold dual or multiple citizenship while living abroad, some estimates put the figure at approximately three to four million (Wong, 2007). With the numbers being as high as they are, and with attitudes changing around the world, and particularly in Europe, about the legality and validity of dual citizenship, it is not surprising that debates have sprung on the Canadian arena about this subject matter. 


\section{Current Debate on Dual and Multiple Citizenship in Canada}

As in every debate (in this case, debates on the international academic arena, the Canadian academic stage as well as in popular media), there are arguments both for and against dual citizenship in Canada. Supporters of dual citizenship argue that citizenship is an "important mechanism for facilitating and promoting immigrant integration" (Macklin \& Crepeau, 2010). A country of immigration like Canada, they argue, would risk the prospect of ending up with a large population of permanent residents who do not naturalize because they do not wish to relinquish citizenship elsewhere, if it were to prohibit dual and multiple citizenship. This would jeopardize the project of fostering, building and stabilizing the national community - a project that is of utmost importance in Canada (Macklin \& Crepeau, 2010).

From an economic perspective, proponents of dual citizenship argue that Canadians with other citizenships can help foster beneficial economic relationships between Canada and the other nations of citizenship (Macklin \& Crepeau, 2010). From a cultural perspective, dual citizens can serve as intermediaries between newcomers and the host society (Macklin \& Crepeau, 2010). From a diplomatic perspective, Canada's influence on the international arena can be augmented by the knowledge and experience of other nations held by dual citizens (Macklin \& Crepeau, 2010). Last but not least, supporters argue that the legality of multiple citizenship makes Canada a competitive and attractive immigration destination for immigrants (Macklin \& Crepeau, 2010). These arguments can all be contested on the grounds that there is no need for multiple citizenship to be legal in Canada to be able to enjoy the financial, cultural, and diplomatic benefits described above. One does not need to be a citizen of another nation to be able to foster economic connections with that nation, a fact well demonstrated by international business. One 
also does not need to be a citizen of another nation to appreciate other cultures, to engage with those cultures and to infuse those into the cultural framework of Canada. There is nothing that would stop Canada to continue from being diverse, culturally and socially open, and globally engaged in trade and economics even if it disallows dual and multiple citizenships.

Those who oppose dual citizenship often refer to the example of dual citizens residing abroad to demonstrate a lack of commitment to Canada. This argument "regards the choice of a citizen to live abroad as proof that the individual is insufficiently committed to Canada or, alternatively, less committed to Canada than to the country in which he or she resides" (Macklin \& Crepeau, 2010). Therefore, they argue, the non-resident citizen should not be entitled to claim the same rights that a resident citizen can claim. Such opposition was taken out of the world of academia and heatedly discussed on the media stage in 2005 with the rescue operation of Canadian citizens out of Lebanon during a conflict with Israel. At that time, Canada managed to swiftly extract about 15,000 Canadian citizens out of Lebanon, an extraction that bore no costs to those who needed rescuing (Cohen, 2007). However, after reports surfaced that approximately 7,000 of those rescued during the conflict had returned to Lebanon 6 weeks later, many reacted with anger (Cohen, 2007). Discussions about Canadian citizens with dual citizenship who do not permanently reside in Canada were plentiful, with commentators pointing out how little value is attributed to the Canadian citizenship. So much so, that Andrew Cohen wrote in the Vancouver Sun in July 2007: "this is the way of the casual Canadian, which is why ours is the easiest citizenship in the world to obtain. To them, this little question of citizenship doesn't really matter. We can have two or three nationalities, can't we? We all have the same rights, don't we?" (Cohen, 2007). 
Opponents often also speak of the public Health Care system in Canada when discussing dual citizenship, especially when it comes to Canadian citizens who do not reside in Canada. It has been argued that some immigrant groups acquire Canadian citizenship for the instrumental purpose of accessing health care (Macklin \& Crepeau, 2010). While it can be argued that it is not only citizenship, but rather residency in a province that provides access to the health care system, a person without citizenship would not be able to travel at will back and forth and still be eligible for health care benefits after three months of residence in Ontario (as one specific example). Those who do not reside permanently in Canada, but still use the Canadian public health care system rarely pay into the system, as health care is funded by funds that are collected through regular taxation. Since non-residents are not obliged to pay taxes in Canada even if they are Canadian citizens, their contributions are minimal at best.

Closely related to the issue of health care, other fiscal considerations become important in this debate. According to the fiscal argument which opposes the legality of dual citizenship, especially in light of non-resident Canadian citizens, since oversees citizens do not reside in Canada, they do not pay taxes, and therefore, should not qualify for certain government services made available through tax revenue - or at least not without paying for them (Macklin \& Crepeau, 2010). Also contested is the right of those citizens to consular services while residing in the country in which they have their second citizenship. Aside from questions of legality, rights and obligations, non-resident citizens do not contribute to the funding of consulates precisely because they do not reside in Canada - in those cases, what are the obligations of Canada to those dual citizens? 
Another key criticism of dual citizenship applies to situations where dual citizens are elected to high public office. Since the office holder represents the Canadian public and serves within the Canadian government, the argument is that the office holder should not have any dual allegiance, or even the appearance of such divided loyalties (Macklin \& Crepeau, 2010). This issue attracted a lot of criticism when Governor General Michaelle Jean's French citizenship and former Liberal Leader Stephan Dion's French citizenship were discussed in the media. Both cases drew sharp commentary. Lynda Hurts, writing for the Toronto Star, discussed the absurdity she found in the notion that one can have dual allegiances and loyalties, and asked what the meaning of citizenship is when one is not expected to pledge loyalty to only one nation (Hurst, 2005). She writes, "Pledging sole allegiance to a new country doesn't entail extinguishing emotional or family ties to the old, but it does formalize the commitment, and commitment is not an unreasonable request" (Hurst, 2005, n.p.). In response to Stephan Dion's dual nationality, Terry Murphy, in his letter to the editor of Richmond News wrote "In my opinion, dual citizenship is a political abomination! If one is not committed enough to a country to accept it as your only nationality, you do not deserve to have the honor of citizenship" (Murphy, 2006, n.p.). He then continues: "If you wish to be a citizen of France, go to it! But if you wish to hold the highest office in Canada, you must have an undivided loyalty to Canada" (Murphy, 2006, n.p.). These and similar sentiments were voiced throughout Canada.

When reviewing literature on dual citizenship, whether scholarly or from popular media, one is left with a clear sense that there are more questions than answers. J.L. Granatstein, in his book Whose War is it? How Canada can survive in the Post 9/11 World in the chapter on Multiculturalism and Canadian Foreign Policy attempts to summarize the questions that are spurred by the legality of dual citizenship. He writes "Whether individuals can have two or 
more allegiances simultaneously may be doubtful, and several serious questions about dual citizenship need to be explored" (Granatstein, 2007). His questions include: in a case where dual citizenship allows a Canadian citizen to vote and be elected for public office in another nation, and assuming that the other nation's interests might not directly align with those of Canada, should that person be allowed to participate in both political arenas? For example, "what will happen when a Canadian with Chinese citizenship gets elected to China's parliament with a mandate to build up military capacity against Taiwan?" (Granatstein, 2007). Also, he wonders what should be Canada's position on the issue of irrevocable citizenship, such as that of Iran and Syria. He asks "do we expect our embassies and consulates to make representations on behalf of dual citizens who get into legal difficulties in the country of their birth, especially if their entered Iran [for example] using an Iranian passport?” (Granatstein, 2007, n.p.). And what about those government jobs that the Supreme Court of Canada decided should be only open to Canadian citizens - should dual citizens be able to hold those? Also, he wonders, what are the obligations of citizens to Canada, and does Canada make any efforts to educate newcomers as to the scope of those obligations? Should Canadians be allowed to serve in foreign militaries? And what are the obligations of the Canadian government to citizens living abroad in their "homeland"? Perhaps the most important question he asks is about the meaning of Canadian citizenship: "does Canadian citizenship mean something, or is Canada just a hotel that the peoples of the world can check into when it suits them?" (Granatstein, 2007, n.p.). 


\section{Traditional, Transnational and Postnational Positions on Dual Citizenship}

To help answer some of these questions, scholars have begun examining the issue of dual citizenship through various theoretical prisms. This section will examine the position of the three most prominent theoretical schools on dual citizenship: traditionalists, transnationalists, and postnationalists.

Traditionalists believe that since countries can only exert sovereignty over the inhabitants of their bounded territories, the assumption is that immigrants gradually lose their attachment to the sending country, and then naturalize by adopting the citizenship of the receiving country through a process of integration. To a large extent, this implies an "either/or" position: one is either a citizen of the home country or a citizens of the receiving country. Some of the predictions of the traditional school on dual citizenship include an assumption of high levels of naturalization and relatively few claims to dual citizenship, the gradual transition from identification with dual nationality to identification with the nationality of the receiving country only, and the assumption that those who claim dual citizenship will also demonstrate the least integration in the host society (Bloemraad, 2004).

Scholars of transnationalism recognize that immigrants' lives transcend borders and that immigrants create transnational lives. Therefore, "dual citizenship is both a cause and an effect of transnationalism" (Bloemraad, 2004, p.394). This school of thought predicts that where dual citizenship is possible, large numbers of immigrants will embrace this status. It also predicts that dual citizenship will increase over time. And lastly, the assumption is that if the world is increasingly transnational, each successive cohort of immigrants will be more likely to claim dual citizenship (Bloemraad, 2004). 
Theories of postnationalism, on the other hand, challenge the whole notion of citizenship in its entirety. Since, they argue, "the advantages of citizenship, such as civil rights and social welfare, are increasingly invested in individuals" there is not more need or use for formal citizenship in one or even several nation states (Bloemraad, 2004). The implication on dual citizenship is that immigrants will shun receiving country's citizenship all together (Bloemraad, 2004).

Indeed, the underlying difference between the three approaches outlined above seem to be about self identification. In the traditional approach, the longer a naturalized dual citizen resides in Canada the more chances are that he/she will self-identify as Canadian as opposed to a dual citizen. Transnationalism supports identification as a dual citizen, and postnationalism begins the rejection process of citizenship as a whole. If citizenship is more than just a legal status but also a moral and emotional status of belonging to a defined (national) community and possessing feelings of loyalty to that community, then traditionalism seems to be the school of thought that uphold those values. Multiculturalism and the legality of dual citizenship only stand in the way of the traditional concept of citizenship. 


\section{Multiculturalism}

Multiculturalism is closely tied to dual citizenship and the debate has touched upon it repeatedly.

Many have argued that the practice of multiculturalism is closely related to the practice of transnationalism (Wong, 2007). The existence of multicultural public policy encourages immigrants to engage in transnational social practices and develop transnational social identities (Wong, 2007). These transnational practices and social identities contribute to the development of transnational ties, connections and identities on the part of immigrants and ethno-religious communities that challenge the traditional conception of citizenship (Satzewich, 2007). 'Multicultural policy facilitates unhealthy transnationalism in the form of engagement in "motherland" issues, dual political loyalties, and the import of "old world" conflicts into Canada" (Satzewich, 2007).

Furthermore, argues Bissoondath in his book titled Selling Illusions: The cult of Multiculturalism in Canada, the real issue with multiculturalism in Canada is that it does not contain any limits to the concepts of tolerance and acceptance (Bissoondath, 1994). He writes:

The Multiculturalism Act suggests no limits to the accommodation offered to different cultural practices, so that a few years ago a Muslim group in Toronto demanded, in the name of respect for its culture, the right to opt out of the Canadian judicial system in favor of Islamic law, a body of thought fundamental to the life and cultural outlook of its practising members. In the opinion of their spokesman, this right should be a given in a truly multicultural society. It is not an argument without philosophical merit $[\ldots]$ and one that evokes questions of the larger context: how far can multiculturalism be taken? Can Canada accommodate citizens whose loyalties do not encompass its long-established legal system?

(Bissoondath, 1994)

On the issue of citizenship he says:

Citizenship is about inclusion. The desire for it emerges from the realization that one's intellectual and emotional loyalties have, through the years, come 
to commit themselves to the idea and actuality of Canada. Once makes a life, puts down roots, and from this feeling of belonging comes the wish to be as fully part of the country as possible.

(Bissoondath, 1994)

Following this logic, it is easy to see how multiculturalism without limits, unhealthy transnational attachments that are encouraged by multiculturalism, and legal dual citizenship status which basically tells immigrants that it is absolutely acceptable not to choose Canada over any other nation, are all tied together in a relationship of reinforcement.

Banting and Kymlicka (2010) disagree with the assessment above. They argue that there is very little evidence to support the claim that social integration is lacking in Canada, despite multiculturalism. They look at language acquisition, racial concentration in poor ghettos, intermarriage rates, development of a sense of attachment in first, second and third generation immigrants, fault-lines on core liberal and democratic values, and participation rates in civic society and find no reason for concern (Banting \& Kymlicka, 2010). They do recognize that the Canadian record is not perfect, to that extent they write:

In sum, the Canadian record on integration is relatively strong. The economic integration of recent immigrants is taking longer; some racial minority immigrants and their children feel less confident that they fully belong; and there [are] important gaps in the representative face of Canadian democracy. In comparison with other Western nations, however, the integrative power of Canadian society for newcomers should not be under-estimated.

(Banting \& Kymlicka, 2010, p.54).

To that, I would argue that Banting and Kymlicka, while recognizing that the Canadian record is not perfect yet strong in comparison to European countries' experiences, fail to recognize that trends are emerging on the Canadian arena that suggest that progress is made in the wrong direction from where it should go. 


\section{"Shallow" and "Instrumental" Citizenship}

When discussing the effects of dual citizenship, some scholars refer to "shallow" and “instrumental" citizenship (Waters, 2003; Manuh, 1998; Conway, Potter \& Bernard, 2008). This section will attempt to define these concepts as they are presented and used in the current scholarly writing.

"Shallow" citizenship refers to citizenship devoid of meaningful intentions towards permanent settlement and integration into and participation in the Canadian national community (Wong, 2007). The assumption is that immigrants holding dual or multiple citizenships cannot be expected to assume a full membership in Canadian society and regard Canada as their primary and sole home by virtue of them holding a second, or several additional citizenships (Wong, 2007). Therefore, transnational practices are problematic as they are considered in relation to traditional conceptions of national citizenship (Wong, 2007). "Instrumental" citizenship refers to situations where Canadian citizenship is acquired for strategic purposes only, such as the flexibility allowed by the Canadian passport, to ensure stability and security, or for the purpose of "cultural capital" accumulation, most often achieve through the acquisition of Canadian education (Waters, 2003). 


\section{Case Studies}

Does the legality of dual (and multiple) citizenship and its close allies - multiculturalism and transnationalism - contribute to the formation of "shallow" or "instrumental" Canadian citizenship? The next section will attempt to answer this question by examining 3 case studies.

In Dual Citizenship or Dual Identity? Does 'Transnationalism' Supplant 'Nationalism' among Returning Trinidadians? Dennis Conway, Robert Potter and Godfrey St. Bernard focus on dual identities of young Trinidadians who have decided to return to Trinidad while still in their thirties and forties. Through this study they attempt to understand what meaning dual citizenship holds for these individuals. They draw their conclusions based on narratives of 36 informants, of which 26 have dual citizenship, to "seek answers to a range of concerns" (Conway, Potter \& Bernard, 2008). After analysing the collected data they conclude that "dual citizenship appears to be an essentially pragmatic strategy, which, once acquired, individuals, marriage partners and even children utilize to advantage because, among other things, it facilitates strategic flexibility" (Conway, Potter \& Bernard, 2008). This conclusion appears to be consistent with the arguments of both "shallow" and "instrumental" citizenship.

Takyiwaa Manuh in Ghanaians, Ghanaian Canadians, and Asantes: Citizenship and Identity Among Migrants in Toronto also attempt to examine the meaning of citizenship, and in this case specifically Canadian citizenship, to Ghanaian immigrants. In this study the findings point towards the conclusion that among this immigrant group, Canadian citizenship is seen as a resource (Manuh, 1998). Manuh found evidence to support the claim that this immigrant group originally viewed their stay in Canada as temporary, and the return to Ghana was the long term goal (Manuh, 1998). However, as this goal became less and less realistic, many have 
opted to apply for Canadian citizenship as it was a resource to ensure security and stability for their families, as Canada was viewed as a nation built on law and order (Manuh, 1998). Also, Canadian citizenship allowed these immigrants access to the Canadian government through which they wanted to influence the situation in Ghana and its future (Manuh, 1998). Thus, in this case as well, evidence point to the validity of precepts of "shallow" and "instrumental" citizenship.

Johanna Waters is also curious about the meaning of Canadian citizenship to immigrants choosing to pursue it. In her study Flexible Citizenship? Transnationalism and Citizenship amongst Economic Immigrants in Vancouver she examines 'astronaut families' (where the man of the house hold - the 'astronaut' - returns to Asia to work shortly after immigration, leaving his spouse and children to undergo the process of settlement in his absence) and 'satellite kids' (where both parents remain in Asia, or leave to Asia shortly after immigration leaving their children to complete their education in Canada in their absence) in Vancouver (Waters, 2003). She finds ample evidence to support the claims of "instrumental" citizenship. After analyzing the data collected she concludes that participants' notions of immigration resonated sharply with theoretical notions of "instrumental" citizenship, particularly, the ways in which specific strategies involving the acquisition of a Canadian passport and the accumulation of 'cultural capital', most notable through acquiring Canadian education, reflected the notion of “instrumental” citizenship (Waters, 2003). 


\section{Discussion}

Traditionally citizenship meant belonging to one nation state. This meant having a legal status of being a citizen with all its entitlements and responsibilities. This meant being equal before the law and sharing in the rights of the citizen body. This also meant, however, that citizens shared an identity tied to their country of citizenship which carried with it emotional and moral ties that clearly delineated between citizenship and non-citizens. Loyalty, emotional attachment, patriotism and national pride were part and parcel of being a citizen. Increased global migration is challenging this conception of citizenship.

Global migration means that a nation is no longer composed of citizens who were born in that nation and raised within its cultural traditions with its values. It means that an increased number of citizens are naturalized. Modern technology also means that immigrants are more diverse and are less likely to have grown up in an environment similar to their environment in the receiving nation. While culturally and socially this might carry many benefits, from the point of view of the concept of citizenship, this raises questions and concerns. As we saw above, citizenship is a concept that is being debated and contested on both the academic arenas.

To further complicate the matter, many receiving nations now have multiculturalism policies enacted which encourage the continued attachment to the values and beliefs carried by immigrants from their home lands. This challenges the traditional value of Canadian citizenship as it clearly signals to recent immigrants and naturalized citizens that loyalty to Canada alone is not expected or encouraged. Couple with multiculturalism, the legality of multiple citizenships in Canada further encourages the retainer of old emotional attachments and loyalties which prevents the development of meaningful attachment to Canada and devalues Canadian citizenship. 
The case studies detailed above seem to support this claim. Canadian citizenship is pursued and acquired as an instrument, a pragmatic tool to achieve mobility and flexibility along with Canadian international protection and improved life style. Instead of viewing Canada as one's true home land people participating in all 3 studies viewed it as just another tool in their tool belt for cosmopolitan living in the world. Where emotion and attachment were expressed, they were more often directed at their country of origin where they still had citizenship rather than towards Canada where they have naturalized.

It is clear that additional research is required to further investigate the connections between multiculturalism, multiple citizenship, and the meaning of Canadian citizenship. It is also necessary to further understand what citizenship as a concept means and what it should mean in the ever increasingly mobile and globalized world. This paper was meant to highlight some of the key discussion already taking place, and urge for research in this sphere to continue. 


\section{Bibliography}

Banting, K. (2010). Is There a Progressive's Dilemma in Canada? Immigration, Multiculturalism and the Welfare State. Canadian Journal of Political Science, 43 (4), 797-820.

Banting, K. \& Kymlicka, W. (2010). Canadian Multiculturalism: Global Anxieties and Local Debates. British Journal of Canadian Studies, 23 (1), 43-72.

Baubock, R. (2002). Farewell to Multiculturalism? Sharing Values and Identities in Societies of Immigration. Journal of International Migration and Integration, 3 (1), 1-16.

Baubock, R. (2009). The Rights and Duties of External Citizenship. Citizenship Studies, 13 (5), 475-499.

Bauder, H. (2014). Domicile Citizenship, Human Mobility and Territoriality. Progress in Human Geography, 38 (1), 91-106.

Bissoondath, N. (1994). Selling Illusions: the Cult of Multiculturalism in Canada. Toronto, ON: Penguin Books Canada.

Bloemraad, I. (2004). Who Claims Dual Citizenship? The limits of Postnationalism, the Possibilities of Transnationalism, and the Persistence of Traditional Citizenship. International Migration Review, 38(2), 389-426.

Bloemraad, I. Korteweg, A. \& Yurdakul, G. (2008). Citizenship and Immigration: Multiculturalism, Assimilation, and Challenges to the Nation-State. Annual Review of Socieology, 34, 153-179.

Brubaker, R. (1992). The French Revolution and the Invention of National Citizenship. Citizenship and Nationhood in France and Germany (35-49). Cambridge, MA: Harvard University Press.

Cohen, A. (2007, July 30). Dual Citizenship Takes Canada's Moderation to Extremes. The Vancouver Sun. http://eaprozy.lib.ryerson.ca/login?url=http://search.proquest.com/ docview/242084909?accountid=13631

Conway, D., Potter, R., \& Bernard, G. (2008). Dual Citizenship or Dual Identity? Does 'Transnationalism' Supplant 'Nationalism' Among Returning Trinidadians? Global Networks, 8(4), 373-397.

Erman, E., \& Follesdal, A. (2012). Multiple Citizenship: Normative Ideals and Institutional Challenges. Critical Review of International Social and Political Philosophy, 15 (3), 279302.

Granatstein, J. L. (2007). Whose War Is It? How Canada Can Survive in the Post 9/11 World. Toronto, ON: HarperCollins Publishers Ltd.

Hurst, L. (2005, Aug 20). Dueling Opinions Over Dual Citizenship; Canada Among First to Allow Dual Citizenships. Toronto Star http://ezproxy.lib.ryerson.ca/login? url=http:// search.proquest.com/docview/438858225? accountid=13631

Krasner, S.D. (2001). Sovereignty. Foreign Policy, 122, 20-29. 
Kymlicka, W. (2011). Multicultural Citizenship within Multinational States. Ethnicities, 11 (3), 281-302.

Levanon, A. \& Lewin-Epstein, N. (2010). Grounds for Citizenship: Public Attitudes in Comparative Perspective. Social Science Research, 39, 419-431.

Loegaard, S. (2012). Naturalization, Desert, and the Symbolic Meaning of Citizenship. Territories of Citizenship (40-59). New York: Palgrave MacMillan.

Macklin, A., \& Crepeau, F. (2010). Multiple Citizenship, Identity and Entitlement in Canada. Institute for Research on Public Policy, (6), 1-36.

Manuh, T. (1998). Ghanaians, Ghanaian Canadians, and Asantes: Citizenship and Identity Among Migrants in Toronto. Africa Today, 45(3-4), 481-494.

Murphy, T. (2006, Dec 08). Dual Citizenship, Dual Allegiance. Richmond News http:// ezproxy.lib.ryerson.ca/login?url=http://search.proquest.com/docview/358862192? accountid $=13631$

Ronkainen, J. K. (2011, Apr). Mononationals, Hyphenationals, and Shadow-Nationals: Multiple Citizenship as Practice. Citizenship studies, 15, 247-263.

Satzewich, V. (2007). Multiculturalism, Transnationalism, and the Hijacking of Canadian Foreign Policy: Pseudo-Problem? International Journal, 63(1), 43-62.

Sejersen, T.B. (2008). "I Vow to Thee My Countries" - The Expansion of Dual Citizenship in the $21^{\text {st }}$ Cnetury. International Migration Review, 42 (3), 523-549.

Soysal, Y.N. (1994). Limits of Citizenship: Migrants and Postnational Membership in Europe. Chicago: University of Chicago.

Stoker, G., Mason, A., \& McGrew, A. (2011). Diminishing Returns? Globalization and the Limits of Citizenship. Prospects for Citizenship. New York: Bloomsbury Academic.

Waters, J. (2003). Flexible Citizens? Transnationalism and Citizenship Amongst Economic Immigrants in Vancouver. The Canadian Geographer, 47(3), 219-234 .

Wong, L. (2007). Transnationalism, Active Citizenship, and Belonging in Canada. International Journal, 63(1), 79-99. 